\title{
GÉNERO
}

\section{Experiencia de hombres condenados por feminicidio}

\author{
Gloria Llanes Gómez
}

\section{Resumen}

Introducción: En Paraguay, cada año alrededor de 50 mujeres son asesinadas por sus parejas o ex parejas, según las cifras oficiales de Feminicidio del Ministerio de la Mujer.

Esta investigación sobre Experiencia de Hombres condenados por Feminicidio, trata de demostrar desde una perspectiva real, tomando al victimario como punto de partida para entender los factores que condujeron al hecho. Feminicidio es considerado como la "muerte violenta de mujeres (asesinato, homicidio o parricidio), por el hecho de ser mujeres" así como "el asesinato de mujeres por razones asociadas con su género".

Objetivo: Analizar experiencia de hombres condenados en el CERESO por Feminicidio y como objetivos específicos: Detallar el contexto psicosocial de hombres condenados en el CERESO por homicidio doloso y/o Feminicidio y conocer las normativas existentes en el país en cuanto a protección a víctimas de Feminicidio en los últimos diez años.

Material y Método: Metodología cuantitativa, de tipo exploratorio-descriptivo. Estudio es de carácter narrativo, que consistió en recolectar datos sobre las experiencias de determinadas personas para describirlas y analizarlas. Se seleccionó 3 casos de condenados por homicidio doloso y Feminicidio recluidos en el CERESO. El primero T, 47 años, de Asunción, condenado Homicidio Doloso Calificado, 22 años de casados, 4 hijos. Problemática: Infidelidad, bajo los efectos del alcohol y la droga. Sentencia: 30 años, más de 10 años de medida de seguridad (Antecedentes para la Ley 5777/16). El segundo entrevistado, B, 51 años, de Encarnación, condenado en dos instancias, 27 años y 19 años, en el año 2012. Casados (22 años) problemática: Infidelidad. Paseros. 4 hijos.

Y el tercero M, 38 años, de Capitán Miranda, Condenado por Homicidio Doloso a 18 años, concubinos. 1 hija menor. Problemática: Infidelidad.

Resultados: Los casos detallados demuestran la violencia psicológica, económica y la victimización en todas las experiencias relatadas. En cuanto al estudio,

1. Universidad Nacional de Itapúa. Facultad de Ciencias Jurídicas

Fue presentado en las XXVI Jornadas de Jóvenes Investigadores de la AUGM en Mendoza - Argentina y publicado en el Libro de Resumen de la XXI Jornada de Jóvenes Investigadores de la AUGM.

E-mail:gloriallanesgomez3@gmail.com

DOI: 10.26885/rcei.foro.2018.98 
los tres asumen una responsabilidad parcial sobre lo realizado, pues si bien reconocen ser los autores materiales del hecho, manifiestan confusión respecto a sus motivaciones, explicándolo como un hecho fortuito, sin intencionalidad real, victimizándose y exteriorizando la culpa hacia sus parejas, quienes serían las culpables de haberlos conducido a cometer este delito.

Conclusiones: Esta investigación tiene como escenario los casos de hombres condenados por Feminicidio, quienes nos relatan sus experiencias, sus vidas, episodios de violencia y el caso por la condena. La violencia ha estado presente a lo largo de toda su vida, ello se hace evidente cuando los entrevistados narran sus historias señalando que han sido víctimas de malos tratos y violencia física en su infancia. Además, demuestran que la violencia se fue naturalizando en sus vidas hasta llegar a ser validar como forma de resolución de conflicto.

Palabras clave: feminicidio, violencia, asesinato.

\section{RefERencias}

Código de Ejecución Penal.

Constitución de la República del Paraguay, 1992.

Ley N¹150/1997, Código Penal Paraguayo.

Ley N¹600/2000, Contra la Violencia Doméstica.

Ley N 5777/2016, de la Protección Integral a las Mujeres, contra toda forma de violencia. 